\title{
FUNGSI TARI BELIAN NAMANG PADA MASYARAKAT KEDANG IPIL DI KABUPATEN KUTAI KARTANEGARA KALIMANTAN TIMUR
}

Oleh:

Dwi Ariyanti

Pembimbing Tugas Akhir: Dr. Rina Martiara, M.Hum dan Drs. Surojo, M.Sn Jurusan Tari, Fakultas Seni Pertunjukan, Institut Seni Indonesia Yogyakarta

Alamat Email: dwiariyanti915@yahoo.com

\section{Ringkasan}

Tari Belian Namang merupakan tari tradisi yang disakralkan yang hidup di masyarakat desa Kedang Ipil Kalimantan Timur. Tari Belian Namang menjadi bagian dari beberapa upacara adat yang dimiliki masyarakat Kedang Ipil, yang merupakan gambaran perjalanan yang sangat jauh dari masyarakat untuk bertemu dengan Dewa. Perjalanan itu dilakukan untuk memberitahu dan momohon izin kepada Dewa, bahwa mereka akan melakukan kegiatan. Mereka berharap agar kegiatan yang akan dilaksanakan dapat berjalan dengan lancar dan terhindar dari roh-roh jahat.

Untuk membantu menemukan jawaban dari permasalahan, maka dipakai teori Struktural Fungsional Radcliffe Brown. Menurut Brown fungsi lebih mengacu dalam struktur sosial yang di dalamnya memiliki relasi antar sistem yang saling berkaitan.

Hasil penelitian tari Belian Namang memiliki tiga fungsi yaitu, fungsi ritual, fungsi sosial, dan fungsi estetis. Fungsi ritual merupakan salah satu wadah yang memposisikan tari Belian Namang menjadi hal yang penting. Salah satu contohnya dalam setiap pelaksanaan upacara ritual, tari Belian Namang selalu dipentaskan dengan tujuan agar apa yang diinginkan oleh para pelaku upacara dapat terlaksana. Fungsi yang kedua yaitu fungsi social, yang menempatkan tari Belian Namang sebagai wadah untuk hidup saling bersosialisasi antar sesama. Pada pementasan tari Belian Namang seluruh lapisan masyarakat turut serta membantu demi kelancaran pementasan. Fungsi ketiga adalah fungsi estetis, yang terlihat dari beberapa gerakan tari Belian Namang. Gerak tari ini membutuhkan kerja sama antar penari. Sikap kebersamaan ini menggambarkan juga sikap keseharian masyarakat Kedang Ipil.

Kata Kunci: Tari Belian Namang, Fungsi, Kedang Ipil 


\begin{abstract}
Namang Belian Dance is a dance tradition that live among rural communities. This dance grows and develops in the village of Kedang Ipil which is the hinterland of East Kalimantan. Namang Belian Dance is a dance that is sacred by the local community, which until now still maintained its existence. Namang Belian Dance became part of some traditional ceremony owned by the people of Kedang Ipil. Namang Belian dance is understood as a picture of a very long journey to meet with God. The journey is done to tell the Gods, that they will do the activity. By asking permission to God, hoping that the activities to be carried out can run smoothly and avoid evil spirits. In this case the main problem is the function of Namang Belian Dance in the community of Kedang Ipil. To help find the answer to the problem, it will borrow Radcliffe Brown's theory of Functional Structural. According to A. R Radcliffe Brown more refers in the social structure in which there are inter-system relations are inter-related.

In this research Belian dance dance has three functions namely, ritual function, social function, and aesthetic function. Ritual function is one of the places that positioned Namang Belian Dance becomes an important thing. One example in every ritual ceremony, Namang Belian Dance always staged with the aim that what is desired by the perpetrators of the ceremony can be done. The second function is the social function. In the social function of placing Namang Belian Dance as a container to live mutual socializing among others.

Performing the dance performance of Namang Dance all layers of society participate to assist the smooth performance and also to establish togetherness. The third function is the aesthetic function. In the aesthetic function can be seen from several movements Namang Belian Dance. In Naman Belian Dance there are several movements that require cooperation between dancers. This cooperation is needed, because if there will be no collision between dancers with each other. This attitude of togetherness that describes the daily attitude of the community Kedang Ipil. With this aesthetic value in Namang Belian Dance increasingly visible, both in terms of motion or the way they perform the show.
\end{abstract}

Keywords: Namian Belian Dance, Function, Kedang Ipil 


\section{PENDAHULUAN}

Desa Kedang Ipil terletak di Kecamatan Kota Bangun Kabupaten Kutai Kartanegara, Provinsi Kalimantan Timur. Desa Kedang Ipil merupakan desa tertua di Kabupaten Kutai Kartanegara yang masih memegang teguh adat. Adat yang masih dipercaya hingga saat ini adalah Adat Lawas. Dalam bahasa Kutai, Adat Lawas berarti kepercayaan lama. Kepercayaan lama artinya masyarakat Kedang Ipil masih melaksanakan kepercayaan yang ditinggalkan nenek moyangnya. Kepercayaan lama yang masih dilaksanakan beberapa upacara ritual, seperti upacara erau, upacara pengobatan, upacara pernikahan, upacara kematian, dan lain sebagainya. Selain upacara ritual, kepercayaan lama yang masih dilaksanakan yaitu mempercayai adanya roh-roh gaib dalam kehidupan mereka. Masyarakat Kedang Ipil percaya bahwa di setiap tempat-tempat tertentu seperti sungai, kayu, pohon, batu, dan lain sebagainya terdapat roh gaib di dalamnya. Roh gaib tersebut dianggap bagian dari kehidupan mereka, sehingga ketika masyarakat mengadakan upacara adat, roh-roh tersebut selalu diundang sebagai tanda hormat kepada roh gaib tersebut.

Manusia merupakan makhluk yang menciptakan dan pengguna budaya. Budaya tersebut terlahir dari hasil pikiran manusia yang kemudian diekspresikan untuk memenuhi kehidupan (Hersapandi, 2014: 17). Desa Kedang Ipil yang berada di Kabupaten Kutai Kartanegara juga memiliki produk budaya hasil dari peninggalan nenek moyang. Budaya tersebut masih diletarikan hingga saat ini (wawancara dengan Bapak Sartin, 24 Januari 2017). Salah satu produk budaya tersebut adalah Tari Belian Namang. Tari Belian Namang merupakan salah satu tari yang sering dipentaskan ketika diadakannya upacara adat. Dalam kedudukannya di upacara adat, Tari Belian Namang dapat dikatakan sebagai wadah untuk menyampaikan pesan kepada roh leluhur. Oleh karena itu, Tari Belian Namang masih dijaga kelestariaanya hingga saat ini sebagai tanda penghormatan kepada leluhur bahwa mereka masih menjaga dan melestarikan peninggalan nenek moyang. Keberadaan suatu tari tentu tidak terlepas dari masyarakat pemiliknya, karena keduanya saling membutuhkan (Hadi 2005: 13). Sama halnya dengan tari Belian Namang yang keberadaanya tidak terlepas dari masyarakat pendukungnya.

Dalam pementasan tari Belian Namang, masyarakat Kedang Ipil saling bekerjasama untuk mempersiapkan kebutuhan pementasan. Para ibu-ibu membantu mempersiapkan sesaji seperti membuat karangan dari janur, sedangkan para laki-laki mempersiapkan janur, mempersiapkan alat musik, membuat properti, dan melakukan hal 
lainnya untuk persiapan. Semua warga saling bergotong royong demi kesuksesan dan kelancaran pementasan.

Tidak ada ketentuan khusus untuk jumlah penari dan jenis kelamin dalam menarikan tari Belian Namang. Semua tergantung dari keinginan si empunya hajat. Akan tetapi, dalam sejarah masyarakat Kedang Ipil, belum pernah tari Belian Namang ditarikan oleh perempuan. Hal ini dikarenakan syarat menjadi seorang penari Belian Namang, harus bisa menguasi mantra atau memang yang selalu diucapkan ketika menari. Tari Belian Namang disajikan dalam bentuk tarian dan mantra. Keduanya berjalan secara bersamaan. Mantra atau mamang dibacakan oleh seorang sesepuh, dan tidak semua orang bisa mempelajarinya. Bahasa serta pengucapan yang sulit membuat mantra ini tidak bisa dipelajari banyak orang.

Gerak yang dilakukan terlihat sederhana, tetapi dalam melakukannya dibutuhkan tenaga yang kuat dan latihan khusus terlebih dahulu. Hal ini karena beberapa gerakan harus dilakukan dengan konsentrasi penuh dan teknik yang tepat. Setiap gerak memiliki makna dan arti berdasar cerita atau dongeng-dongeng yang dipercaya oleh warga setempat.

Gerakan pada tari Belian Namang merupakan aspek-aspek dari gerak berjalan dan terbang ke khayangan. Gerak tersebut tidak murni dilakukan sebagaimana mestinya gerak terbang, melainkan diubah menjadi gerak berputar dengan sangat cepat sambil memegang benyawan (janur kuning yang berada di tengah panggung) tanpa menginjak panggung. Gerakan yang dilakukan pada tari Belian Namang lebih berpusat pada kaki, karena selama menari mereka terus berjalan dan berputar sampai tarian berakhir.

Jenis iringan tari Belian Namang adalah tamuyan (wawancara tanggal 24 Januari 2017). Alat musik yang digunakan dalam tari Belian Namang terdiri dari empat buah instrumen, yaitu penyalit, gendang panjang, gong kecil, dan kelentangan. Keempat alat musik ini merupakan alat musik yang sudah sudah turun temurun diwariskan. Dari zaman ke zaman alat musik peninggalan ini dirawat dan dicat ulang apabila cat mulai memudar. Di Kedang Ipil hanya satu orang saja yang memiliki alat musik yang biasanya digunakan untuk mengiringi beberapa tarian yang ada.

Tata rias dan busana merupakan bagian yang penting dalam sebuah pertunjukan. Dengan ini tata rias yang digunakan dalam Tari Belian Namang tidak cenderung berlebihan. Bahkan para penari Belian Namang tidak menggunakan make up sama sekali. Wajah mereka terlihat natural apa adanya. Dalam menari, para penari Belian Namang bertelanjang dada. Busana yang 
dipakai adalah kain, selendang, dan krincingan yang dililitkan di bagian pinggang, serta topi untuk ikat kepala.

Ruang pentas tari Belian Namang bersifat terbuka, tergantung dari kebutuhan. Biasanya tari Belian Namang dipentaskan di panggung yang sengaja dibuat. Ketika acara sudah selesai maka panggung tersebut akan dibongkar kembali. Panggung tersebut terbuat dari kayu dan berbentuk rumah tanpa dinding. Ada juga tari Belian Namang yang ditarikan di tanah lapang, yang berfungsi untuk mendatangkan angin atau hujan. Tetapi upacara ini sudah jarang dilaksanakan.

Tari Belian Namang sebagai wujud tari tradisional yang memiliki nilai sakral, keberadaannya tidak terlepas dari masyarakat pendukungnya. Untuk mengupas fungsi tari Belian Namang pada pada masyarakat Kedang Ipil, dipakai teori fungsional-struktural Radcliffe Brown. Brown mengatakan bahwa sebuah struktur tidak dapat terlepas dari sebuah fungsi, sehingga kedua bagian tersebut saling berkaitan satu dengan yang lainnya. Brown melihat adanya konsep fungsi dengan menggunakan sebuah analogi, bahwa kehidupan sosial sebagai kesatuan kehidupan organik sesuai tubuh manusia (Radcliffe Brown 1980: 209).

\section{PEMBAHASAN}

Tari Belian merupakan salah satu tari tradisional yang dimiliki oleh masyarakat desa Kedang Ipil, yang secara turun-temurun selalu ditampilkan dalam upacara ritual. Dalam bahasa Kutai, belian artinya berputar (wawancara 24 Januari 2017). Di Kalimantan Timur, Belian juga dimiliki oleh beberapa suku, seperti suku Paser dan suku Dayak. Namun pengertian Belian yang dimiliki oleh setiap suku berbeda. Selain berbeda pengertian, beberapa hal lain seperti bentuk pertunjukan, kostum, iringan, dan mantra juga memiliki perbedaan.

Belian yang tumbuh dan berkembang di masyarakat Kedang Ipil dahulunya adalah suatu upacara yang biasa disebut dengan upacara Belian. Dalam upacara Belian tersebut terdapat suatu tari. Tari itu selalu mengiringi upacara Belian, sehingga masyarakat menyebut tari tersebut menjadi tari Belian. Sejak saat itulah upacara Belian berubah menjadi tari Belian. Dahulu tari Belian digunakan untuk penyembuhan orang sakit. Orang sakit yang dimaksudkan di sini bukanlah orang yang sudah sakit parah, melainkan orang yang sudah meninggal. Pada waktu itu, orang yang sudah meninggal oleh masyarakat Kedang Ipil disebut "sedang sakit". Pada saat itu orang yang dibeliankan bisa hidup kembali. Kekuatan Belian pada waktu itu memang sangat kuat. Cerita tersebut 
berdasarkan atas mitos-mitos yang berkembang dan diceritakan secara turun temurun dari mulut ke mulut pada masyarakat Kedang Ipil. Seiring dengan perkembangan zaman, akhirnya tari Belian digunakan untuk beberapa kegiatan. Hal ini disebabkan oleh sistem religi atau kepercayaan yang mereka anut, karena sistem religi merupakan kepercayaan terhadap sesuatu hal yang tidak ada di dunia nyata, sehingga mempengaruhi kehidupan masyarakatnya (Sumaryono, 2011: 36).

Dalam kepercayaan masyarakat Kedang Ipil, tari Belian Namang bukanlah ciptaan manusia melainkan ditemukan oleh sosok siluman monyet atau berok (dalam bahasa Kutai) yang bernama Selimau (wawancara dengan bapak Sartin tanggal 24 Januari 2017). Ketika itu Selimau sedang membuat perahu di tepi sungai Namang. Di saat Selimau sedang asik membuat perahu, Selimau mendengar suara ribut di dalam hutan belantara. Rasa penasaran dan keingintahuan Selimau, membuat Selimau masuk ke dalam hutan tersebut untuk melihat apa yang sedang terjadi. Ternyata di dalam hutan tersebut Selimau melihat beberapa monyet sedang berpesta. Mereka membunyikan alat musik sambil menari bersama-sama. Melihat kejadian itu Selimau tertarik dan ikut menari bersama monyet-monyet tersebut. Sejak saat itulah muncul istilah Upacara Belian yang saat ini menjadi tari Belian. Kata Namang berasal dari nama daerah di mana Tari Belian tersebut ditemukan, sehingga nama tari tersebut menjadi Tari Belian Namang.

Dari beberapa cerita yang berkembang di masyarakat Kedang Ipil, Belian Namang merupakan tari yang menceritakan kisah perjalanan. Perjalanan tersebut bukanlah perjalanan yang dilakukan oleh masyarakat setempat, melainkan perjalanan yang dilakukan oleh roh leluhur mereka. Perjalanan tersebut dilakukan untuk memberitahu Dewa bahwa mereka akan melakukan kegiatan atau upacara adat. Dapat dikatakan, penari Belian Namang tersebut merupakan personifikasi dari roh-roh yang melakukan perjalanan untuk bertemu Dewa. Para penari Belian Namang menemui Dewa untuk memohon izin, agar upacara yang dilakukan dapat berjalan dengan lancar dan terhindar dari gangguan-gangguan roh jahat.

Perjalanan yang mereka lalui tidaklah lancar, dalam melakukan perjalanan pasti menemukan jalan yang berkelok-kelok. Oleh karena itu, terdapat gerakan berjalan sambil membentuk huruf S. Gerakan tersebut merupakan gambaran dari perjalanan mereka, bahwa perjalanan itu melewati bukit, naik turun gunung, melewati kelokan-kelokan sungai. Di setiap desa yang dilalui, mereka memberi pengumuman bahwa mereka akan 
melakukan upacara adat. Gerakan memberitahu di setiap desa ini dapat dilihat dari perpindahan gerak. Ketika melakukan gerak berjalan sambil berputar, lalu setelah selesai para penari kembali berjalan seperti biasa. Gerakan ini mengandung arti bahwa mereka memberitahu setiap desa yang dilalui. Kemudian ketika penari bergerak kembali, artinya penari melanjutkan perjalanan lagi. Dari beberapa makna gerak yang telah disebutkan, masih banyak lagi makna-makna gerak yang terkandung dalam Tari Belian Namang yang umumnya bermakna perjalanan.

\section{A. Fungsi Ritual}

1. Sebagai Sarana Komunikasi Dengan Makhluk Ghaib

Tari Belian Namang selalu mengiringi berbagai upacara adat yang dimiliki masyarakat Kedang Ipil. Hal ini karena Belian Namang dipercaya memiliki unsur magis yang sangat kuat. Dalam menampilkan Tari Belian Namang, masyarakat Kedang Ipil mempercayai bahwa fungsi yang terdapat pada Tari Belian Namang mampu mengabulkan keinginan masyarakatnya. Fungsi ritual tari Belian Namang pada masyarakat Kedang Ipil di antaranya sebagai komunikasi kepada rohroh gaib.

Pelaksanaan upacara adat yang dilakukan masyarakat Kedang Ipil tidak hanya sarana permohonan dan rasa syukur saja. Upacara adat juga dilakukan untuk sarana komunikasi terhadap roh-roh leluhur mereka. Dengan adanya komunikasi tersebut, masyarakat berharap agar para leluhur bisa mendengarkan apa yang diinginkan oleh warga. Dengan adanya komunikasi, maka akan terjalin hubungan yang baik antara masyarakat dan roh leluhur, sehingga antar keduanya tidak akan saling mengganggu.

Berbicara masalah komunikasi ternyata tidak terlepas pada sebuah bentuk interaksi sosial. Komunikasi merupakan salah satu proses penyampaian pikiran atau perasaan kepada orang lain dengan menggunakan lambang atau simbol melalui sebuah media (Onong Uchjana Effendi, 1984: 14). Komunikasi yang dilakukan masyarakat Kedang Ipil kepada roh leluhur dengan menggunakan media, yaitu Trai Belian Namang. Pada dasarnya tari tradisional hidup dan berkembang dalam pola pelembagaan ritual yang masih mewarisi budaya primitif yang bersifat magi maupun magis. Masyarakat Kedang Ipil selalu mengikutsertakan tari Belian Namang ketika diadakannya upacaraupacara ritual atau adat. Tujuan diadakannya tari Belian Namang adalah untuk menghadirkan roh para leluhur dengan mengharapkan berkah keselamatan bagi masyarakat yang melakukan upacara ritual. Berbagai macam doa yang dipanjatkan 
bertujuan agar terhindar dari gangguan roh-roh jahat juga dilakukan dalam upacara ritual. Hal ini dilakukan karena upacara ritual dianggap suatu kegiatan yang mulia.

Masyarakat Kedang Ipil mempercayai bahwa roh para leluhur hadir dalam setiap upacara adat yang mereka lakukan. Oleh karena dengan menampilkan tari Belian Namang dalam upacara adat, masyarakat meyakini roh leluhur akan hadir untuk memberikan keselamatan dan perlindungan bagi masyarakat Kedang Ipil.

\section{Sebagai Ritual Tolak Bala}

Fungsi yang kedua yaitu sebagai tolak bala dalam upacara erau. Upacara erau yang akan dibahas di sini adalah upacara erau yang diselenggarakan oleh pihak Kedhaton Kutai Kartanegara. Upacara erau selalu dilaksanakan selama satu tahun sekali. Upacara erau merupakan upacara adat terbesar di Kabupaten Kutai Kartanegara. Erau berasal dari kata eroh yang berarti ramai, riuh, ribut suasana yang penuh dengan suka cita (Murhansyah, 2006: 9) Tidak ada larangan untuk mengikuti upacara erau tersebut. Semua warga Kutai Kartanegara maupun yang berasal dari luar boleh mengikuti upacara erau.

Rangkaian kegiatan upacara erau dilakukan selama 7 hari 8 malam. Hari pertama dilaksanakan pembukaan erau dengan menampilkan tarian-tarian tradisonal seperti tari Jepen, tari Gantar, dan jenis-jenis tari masyarakat Dayak lainnya. Pembukaan erau biasanya dilaksanakan di Stadion atau Gedung Olahraga. Di tempat-tempat wisata lainnya juga dibuka panggung pertunjukan untuk menampilkan berbagai macam jenis tarian, baik dari dalam negeri ataupun luar negeri. Dengan dipergelarkannya pertunjukan yang ada di berbagi tempat wisata, menjadikan Kota Tenggarong semakain ramai. Keadaan semacam ini membuat seluruh warga Kota Tenggarong merasakan ramainya upacara erau.

Pusat ritual dalam upacara erau ini adalah di Kedhaton Kutai Kartanegara. Khusus daerah Kedhaton, tidak semua orang boleh masuk. Dahulu hanya pihakpihak Kedhaton saja yang bisa menikmati suasana ritual di dalam Kedhaton. Seiring dengan berkembangnya zaman, para turis dan duta wisata Kota Tenggarong boleh masuk ke dalam Kedhaton. Masyarakat yang tidak bisa masuk ke dalam Kedahton, dapat menikmati rangkaian acara ritual melalui layar yang sengaja dibuat, dan diletakkan di depan samping Kedhaton. 


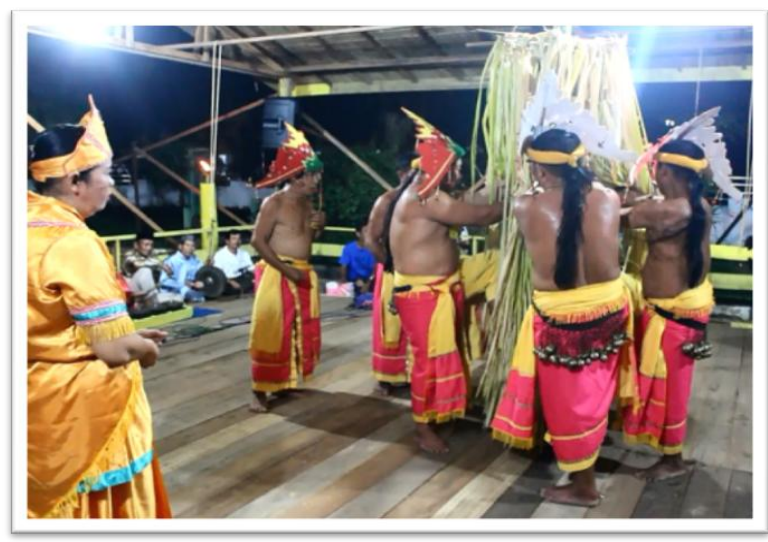

Gambar 1: Tari Belian Namang pada upacara Erau di Kabupaten Kutai Kartanegara (Dok: Dwi Ariyanti 26 Agustus 2016)

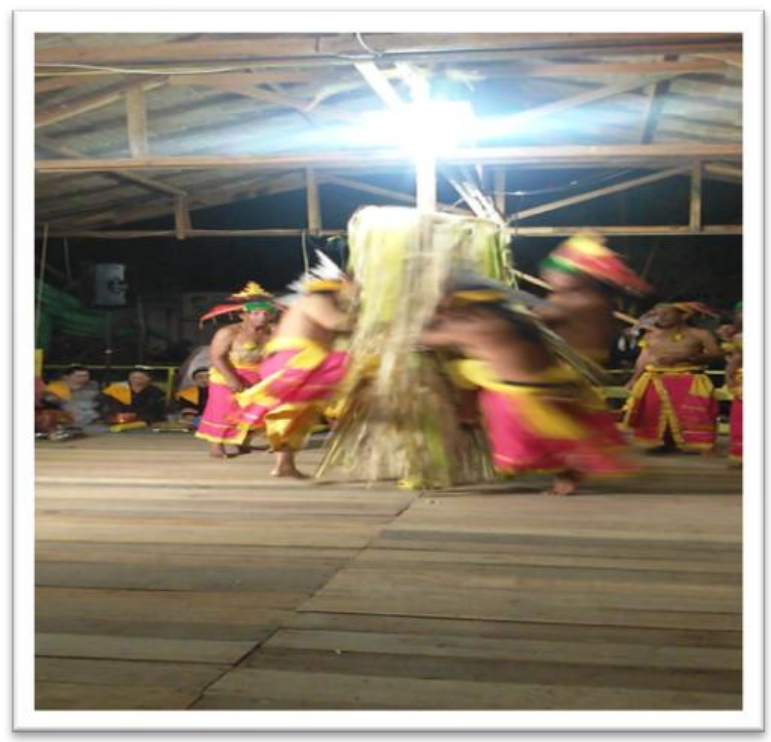

Gambar 2: Gerak berputar sambil memegang bambu pada upacara erau di Kabupaten Kutai Kartanegara (Dok: Dwi Ariyanti 26 Agustus 2016)

Sebelum masuk ke acara yang ada di dalam Kedhaton, tari Belian Namang ditampilkan terlebih dahulu sebagai penghantar. Tari Belian Namang dipentaskan diawal sebelum memasuki acara Kedahton dengan tujuan untuk tolak bala agar acara di dalam Kedhaton terhindar dari gangguan-gangguan roh jahat. Selain sebagai tolakbala, juga digunakan untuk berkomunikasi kepada roh-roh leluhur.
Komunikasi tersebut bertujuan untuk mengundang roh-roh nenek moyang untuk ikut serta dalam pelaksanaan upacara adat erau.

\section{Sebagai Sarana Pengobatan}

Dahulu Tari Belian Namang digunakan sebagai sarana pengobatan untuk orang sakit. Orang sakit yang dimaksudkan di sini bukanlah orang yang sedang sakit keras, melainkan orang yang sudah meninggal. Menurut mitos yang berkembang di masyarakat Kedang Ipil, dahulu orang yang sudah meninggal disebut orang yang menderita sakit keras. Kemudian setelah orang tersebut meninggal selama tiga hari, diadakanlah upacara Belian dengan tujuan agar orang tersebut bisa hidup kembali. Berdasarkan mitosnya, upacara Belian pada saat itu mampu menghidupkan kembali orang yang sudah meninggal. Nilai sakral yang terkandung dalam upacara Belian pada waktu itu sangatlah kuat.

Proses pengobatan Tari Belian Namang juga menggunakan beberapa mantra dengan tujuan untuk menjelajahi negeri para Dewa. Dewa tersebut diundang dalam pelaksanaan upacara pengobatan untuk membantu proses pengobatan. Selain untuk mengundang para Dewa, mantra yang diucapkan juga untuk mengusir roh-roh jahat yang akan menggangu jalannya ritual. 
Seiring dengan perkembangan zaman, Tari Belian Namang sudah memiliki banyak fungsi. Dalam hal pengobatan orang sakit, saat ini bukanlah orang sakit yang sudah meninggal. Orang sakit yang disembuhkan saat ini adalah orang sakit yang tidak bisa disembuhkan secara medis tetapi belum meninggal. Saat ini Tari Belian Namang tidak bisa lagi digunakan untuk menghidupkan orang yang sudah meninggal. Belian Namang hanya bisa digunakan untuk menyembuhkan orang sakit, seperti sakit karena diguna-guna atau diganggu roh jahat.

Menurut Brown, kepercayaan budaya primitif seperti hal tersebut di atas bukanlah dari segi psikologi manusia, melainkan mengenai hubungan atara upacara dengan nilai-nilai yang terkandung di dalamnya serta merupakan bagian terpenting dalam kehidupan manusia dengan melakukan kepercayaan lama hingga saat ini. (A R Radcliffe Brown, 1980: 170). Penjelasan ini dapat dikatakankan bahwa nilai yang terkandung dalam upacara ritual sangat dijunjung tinggi oleh masyarakat zaman dahulu. Seperti upacara pengobatan yang dimiliki oleh desa Kedang Ipil, nilai-nilai yang terdapat dalam upacara ritual yang mereka miliki masih dilaksanakan hingga saat ini.

\section{B. Fungsi Sosial}

Desa Kedang Ipil merupakan desa Kutai tertua di Kabupaten Kutai Kartanegara yang dalam kehidupan sehari-harinya masih menggunakan pola tradisional (wawancara dengan Bapak Sartin, 24 Januari 2017). Dalam kehidupan sehari-hari masyarakat setempat saling bahu-membahu satu dengan yang lainnya. Beberapa kegiatan yang dilaksanakan, selalu melibatkan seluruh lapisan masyarakat setempat. Misalnya saja dalam pementasan tari Belian Namang. Seluruh warga baik laki-laki ataupun perempuan saling membantu. Kaum laki-laki membantu mencari janur untuk kelengkapan sesaji dan mencari perlengkapan pentas seperti, kostum, alat musik, property, dan lain sebagainya. Kaum perempuan membuat dan menyiapkan sesaji. Seluruh masyarakat saling membantu, sehingga terjalin rasa kebersamaan dan solidaritas yang tinggi.

Kegiatan adat yang dimiliki desa Kedang Ipil yang melibatkan seluruh anggota masyarakat adalah upacara pengukuhan Kepala Desa. Dalam upacara pengukuhan Kepala Desa, tari Belian Namang juga dipentaskan. Hal ini karena Tari Belian Namang tidak dapat dipisahkan dari beberapa upacar ritual yang ada di Desa Kedang ipil. Dalam pelaksanaan upacara ritual selain untuk menyampaikan permohonan kepada Dewa, kegiatan tersebut juga untuk pengikat solidaritas masyarakat setempat. Adanya beberapa kegiatan adat, membuat masyarakat setempat dapat mengenal ataupun bersosialisasi dengan warga yang lainnya. 


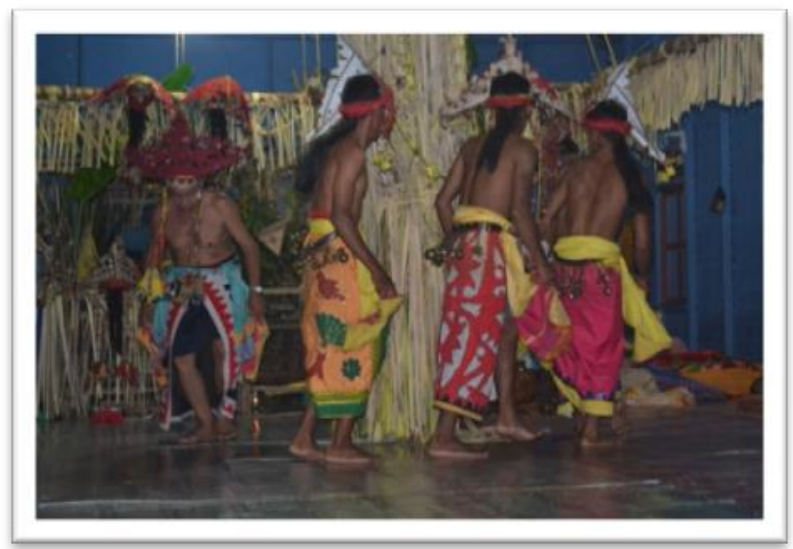

Gambar 3: Pementasan Tari Belian Namang pada saat upacara Pengukuhan Kepala Desa Kedang Ipil. (Dok: Bapak Sartin, 2014)

Menumbuhkan kekuatan spiritual dalam pementasan Tari Belian Namang tidak hanya bekerja sama dalam persiapan pementasan Tari Belian Namang saja. Menjadi pendukung dan penonton tari Belian Namang juga dilakukan oleh masyarakat setempat demi kelancaran pementasan. Dengan ini Tari Belian menempati posisi terpenting pada kehidupan sosial masyarakat Kedang Ipil. Adanya tari Belian Namang membuat masyarakat Kedang Ipil dapat menjalin hubungan yang baik dengan warga yang lainnya.

\section{Fungsi Estetis}

Nilai estetis pada masyarakat Kedang Ipil dapat dilihat dari kesederhanaan kehidupan mereka. Masyarakat Kedang Ipil hidup dengan penuh kesederhanaan dan rasa solidaritas yang tinggi. Unsur kesederhanaan tampak pada tari Belian Namang yaitu dari segi gerak serta pementasan yang sangat sederhana. Pementasan Tari Belian Namang memang tampak sangat sederhana, tetapi tari tersebut memiliki makna dan nilai yang tinggi. Keindahan suatu tari bukan hanya terlihat dari keterampilan penari yang bisa melakukan gerakan dengan lemah gemulai, tetapi bentuk tari akan terlihat mempesona jika isi dari tari tersebut mengandung makna atau pesan tertentu (Y. Sumandiyo Hadi, 2005: 14). Dalam Tari Belian Namang gerakan yang dilakukan mayoritas gerakan berputar. Putaran tersebut menggambarkan kehidupan manusia yang selalu berputar. Bahwasanya manusia tidak selamanya berada di atas. Hal ini yang mengajarkan masyarakat Kedang Ipil untuk bisa bersosialisasi dengan warga yang lainnya, agar dapat saling membantu serta memiliki rasa empati terhadap sesame.

Nilai estetis lain yang nampak pada tari Belian Namang adalah kebersamaan serta kerja sama antar penari. Dalam tari Belian Namang terdapat beberapa gerakan yang membutuhkan kerja sama antar penari satu dengan yang lainnya. Hal ini dilakukan agar tidak terjadi kecelakaan dalam pementasan. Rasa kebersamaan dan kerja sama antar penari menggambarkan kehidupan masyarakat Kedang Ipil. Melaksanakan pementasan khususnya tari Belian Namang, seluruh masyarakat Kedang Ipil saling membantu demi kelancaran pementasan. Masyarakat 
saling bekerja sama baik dari segi persiapan perlengkapan pementasan ataupun saat berjalannya pementasan. Rasa kebersamaan dan kerja sama inilah yang tampak pada tari Belian Namang, sehingga keindahan dalam tari tersebut akan tampak.

\section{PENUTUP}

Tari Belian Namang merupakan tari tradisional yang tumbuh dan berkembang di masyarakat Kedang Ipil. Kebiasaan lama yang masih dilaksanakan hingga sekarang seperti menyelenggarakan beberapa upacara adat, dan mempertunjukkan tari Belian Namang. Tari Belian Namang pada awalnya merupakan upacara pengobatan yang biasa disebut dengan upacara Belian. Upacara Belian pada waktu itu selalu didampingi oleh suatu tari, sehingga akhirnya masyarakat menyebut tari tersebut dengan nama tari Belian. Saat ini mendapat tambahan Namang yang menunjuk pada tempat di mana upacara Belian ini hadir. Saat ini orang mengenal upacara Belian menjadi tari Belian Namang.

Fungsi Tari Belian Namang pada masyarakat Kedang Ipil yaitu: fungsi ritual, fungsi sosial, dan fungsi estetis. Fungsi ritual menempatkan tari Belian Namang sebagai suatu yang penting. Dalam berbagai pelaksanaan upacara ritual yang dilakukan masyarakat desa Kedang Ipil, selalu tidak terlepas dari tari Belian Namang. Hal ini karena masyarakat setempat percaya akan adanya kekuatan magis dalam tari Belian Namang. Masyarakat percaya bahwa tari Belian Namang mampu menyampaikan permohonan mereka kepada Dewa dan juga masyarakat yakin bahwa tari Belianlah yang dikehendaki oleh Dewa. Oleh karena itu masyarakat setempat memposisikan Tari Belian Namang sebagai suatu tari ritual.

Fungsi yang kedua yaitu fungsi sosial. Dalam pementasan Tari Belian Namang, melibatkan seluruh lapisan masyarakat Kedang Ipil. Seluruh masyarakat saling bahumembahu demi kelancaran pementasan. Masyarakat berperan sebagai pendukung ataupun penonton pada tari Belian Namang. Masyarakat juga berperan sebelum pementasan dan saat pementasan. Dengan adanya kegiatan semacam ini, masyarakat akan lebih mengenal satu dengan yang lainnya dan menjalin komunikasi yang baik. Hal ini dapat dikatakan bahwa, tari Belian Namang memiliki peran dalam kehidupan sosial. Adanya tari Belian Namang membuat masyarakat menjalin hubungan yang baik antar warga.

Fungsi yang ketiga yaitu fungsi estetis. Nilai estetis pada masyarakat Kedang Ipil dapat dilihat dari kesederhanaan kehidupan mereka. Masyarakat Kedang Ipil hidup dengan penuh kesederhanaan dan rasa solidaritas yang tinggi. Unsur kesederhanaan 
tampak pada Tari Belian Namang yaitu dari segi gerak serta pementasan yang sederhana. Pementasan tari Belian Namang memang tampak sangat sederhana, tetapi tari tersebut memiliki makna dan nilai yang tinggi. Gerak yang sederhana tersebut juga membutuhkan kerja sama santar penari. Kerja sama ini sangat dibutuhkan, karena jika tidak, akan terjadi tabrakan antar penari yang satu dengan yang lainnya. Sikap kebersamaan dan kerja sama ini yang menggambarkan sikap keseharian masyarakat Kedang Ipil.

\section{DAFTAR SUMBER ACUAN}

\section{A. Sumber Tercetak}

Effendi, Onong Uchjana. 1984. Ilmu Komunikasi. Bandung: Remaja Karya.

Brown, A. R Radcliffe. 1980. Struktur dan Fungsi dalam Masyarakat Primitif. terjemahan $\mathrm{Ab}$ Razak Yahya. Kuala Lumpur: Dewan Bahasa dan Pustaka Kementrian Pelajar Malaysia.

Hadi, Y Sumandiyo. 2005. Sosiologi Tari Sebuah Pengenal Awal. Yogyakarta: Pustaka.

Hersapandi. 2014. Ilmu Sosial dan Budaya Sebuah Pengantar. Yogyakarta: Badan Penerbit Institut Sni Indonesia Yogyakarta.
Murhansyah. 2006. Erau Kemilau Kearifan Masa Silam. Pondok Gede: Ganeca Exact.

Sumaryono. 2011. Antropologi Tari dalam Prespektif Indonesia. Yogyakarta: Badan Penerbit ISI Yogyakarta.

\section{B. Narasumber}

Murad 40 th, Pemusik Belian Namang

Sartin 47 th, Penari Belian Namang 